\title{
First aggregation of grey nurse sharks (Carcharias taurus) confirmed in Western Australia
}

\author{
Alexandra M. Hoschke ${ }^{\dagger}$ and Glen J. Whisson ${ }^{*+}$
}

\begin{abstract}
Background: The population of grey nurse sharks (Carcharias taurus) found along the coast of Western Australia (WA) is listed as Near Threatened under the International Union for Conservation of Nature and yet has been the subject of minimal targeted research in WA. In contrast, the eastern Australian and southwest Atlantic subpopulations of $C$. taurus are afforded Critically Endangered status following a much greater research effort. Aggregation sites are important in the life cycle of $C$. taurus for mating and pupping, and their identification underpins conservation efforts. The present study set out to complete a detailed, multi-year assessment of $C$. taurus at the Point Murat Navy Pier in Exmouth, WA, where recreational divers have reported occasional sightings over many years.
\end{abstract}

Results: Between 2007 and 2012 a permanent subsurface video camera was deployed, with the subsequent analysis of over 1000 days of underwater footage revealing sixteen C. taurus individuals, which were positively identified using spot patterns. Ten sharks returned to the site over multiple years, with presence/absence data displaying a strong negative correlation with water temperature. Sharks were never recorded above a mean daily sea temperature of $25.5^{\circ} \mathrm{C}$, indicating a possible upper threshold for aggregations of this population.

Conclusions: While the study revealed a comparatively small gathering of $C$. taurus, the authors maintain that the systematic nature of visitations by individual sharks over a number of years qualifies the location as a noteworthy aggregation site, the first ever confirmed in Western Australia, and the northernmost documented for C. taurus in Australia to date.

Keywords: Carcharias taurus, Aggregation, Site philopatry, Temperature threshold, Grey nurse shark

\section{Background}

The grey nurse shark, Carcharias taurus (Rafinesque 1810), inhabits inshore sub-tropical to temperate waters around continental land masses (Ebert et al. 2013). It is found on the continental shelf to a depth of at least $230 \mathrm{~m}$ (Otway and Ellis 2011) but is more commonly observed in caves or sandy gutters close to the mainland or around islands (Pollard et al. 1996). In Australia, two distinct populations have been described based on genetic diversity (Stow et al. 2006; Ahonen et al. 2009). The eastern population shows low genetic variation, and despite being protected in New South Wales since 1984 (Pollard et al. 1996) numbers were thought to be

\footnotetext{
* Correspondence: gjwhisson@hotmail.com

${ }^{\dagger}$ Equal contributors

Aqua Research and Monitoring Services, 5 Beenong Rd, Darlington, Western

Australia 6070, Australia
}

(c) 2016 Hoschke and Whisson. Open Access This article is distributed under the terms of the Creative Commons Attribution 4.0 International License (http://creativecommons.org/licenses/by/4.0/), which permits unrestricted use, distribution, and reproduction in any medium, provided you give appropriate credit to the original author(s) and the source, provide a link to the Creative Commons license, and indicate if changes were made. The Creative Commons Public Domain Dedication waiver (http://creativecommons.org/publicdomain/zero/1.0/) applies to the data made available in this article, unless otherwise stated.

declining with total population estimates as low as 300 individuals (Otway et al. 2000, 2003). More recent studies on the East Coast have, however, identified 931 individuals at 19 aggregation sites between 2004 and 2008 (Bansemer and Bennett 2009, 2011). The C. taurus population in Western Australia (WA) is genetically distinct from the eastern Australian population due to its geographic isolation (Stow et al. 2006; Ahonen et al. 2009) and while its range is predominantly in the coastal waters in the South West of WA, the species has been recorded at the North West Shelf (Pogonoski et al. 2002; Department of the Environment 2014) and the Timor Sea (Momigliano and Jaiteh 2015) off the far North West coast. Carcharias taurus has been protected in WA waters since 1999 and in all Commonwealth waters since 1997. Abundance and distribution for the WA population were previously estimated from bycatch data from 
demersal gillnet fisheries, with a mean annual catch of 77 and a stable catch per unit effort between 1989 and 1997 (Cavanagh et al. 2003). Based on this data the WA population was listed as Near Threatened on the IUCN Red List (Pollard et al. 2003) and Vulnerable under the Environment Protection and Biodiversity Conservation Act 1999. However, bycatch reporting from demersal gillnet fisheries ceased in 1997 (McAuley and Simpfendorfer 2003) and C. taurus population data have subsequently been limited to ad hoc accounts from commercial gillnet fisheries (Chidlow et al. 2006).

Although there is little documented information about C. taurus in WA, it is likely to have a similar life history to populations in other parts of the world where mature female sharks undergo a biennial or triennial migration north and south along the coast to mate and breed (Smale 2002; Dicken et al. 2006, 2007; Bansemer and Bennett 2009). Tagging studies in New South Wales indicated a northerly migration in autumn and winter, and a southerly migration over spring/summer (Otway and Ellis 2011); however, photo identification studies along Australia's eastern coastline have indicated a more complex migration pattern depending on the sex and maturity of the sharks (Bansemer and Bennett 2011). The only documented tagging study in WA tracked three juveniles and one adult female between June and December 2003 (McAuley 2004). The juveniles travelled up to $489 \mathrm{~km}$ north from Rottnest Island or Ledge Point before turning south, while the adult female did not appear to move far from her tagged location near the Abrolhos Islands off the Mid-West coast. The tagged sharks favoured water depths between 20 and $60 \mathrm{~m}$ but ranged between 0 and $146 \mathrm{~m}$ in water temperatures between 16 and $22{ }^{\circ} \mathrm{C}$.

Carcharias taurus displays adelphophagous reproduction (cannibalism within both the egg case and each uterus) and therefore has a maximum of two pups per litter following a gestation period of 9-12 months (Last and Stevens 2009). Pups are born at around $100 \mathrm{~cm}$ total length (TL), males mature at 190-195 cm and females at 220-230 cm TL (Last and Stevens 2009). Sexual maturity has been estimated at 6-7 years for males and 9-10 years for females in the western North Atlantic, with maximum lengths of $296 \mathrm{~cm}$ (female) and $250 \mathrm{~cm}$ (male) using von Bertalanffy growth curves on a sample of 48 males and 48 females (Goldman et al. 2006). However, males were identified as immature at $202 \mathrm{~cm}$ and mature at $220 \mathrm{~cm}$ from a small sample from the east coast of southern Africa (Bass et al. 1975), and two males of $3 \mathrm{~m}$ TL and a female of $3.2 \mathrm{~m}$ TL have been reported from sharks in captivity in Sydney (Gordon 1993) so there may be variation in growth and maturity rates for different populations. Recent radiocarbon studies on $C$. taurus from the western Northern Atlantic and southwestern Indian Ocean indicate lifespans of at least 40 years for females and 34 years for males (Passerotti et al. 2014). Given their biennial reproductive cycle and resulting slow population growth, $C$. taurus are vulnerable to over exploitation (Compagno 2001; Pollard and Smith 2009).

Aggregation sites are important in the life cycle of $C$. taurus for both mating and pupping (Cavanagh et al. 2003; Chidlow et al. 2006; McAuley 2004); and although a number of these sites have been identified in Queensland and New South Wales (Otway et al. 2003; Bansemer and Bennett 2009) and the importance of protecting these habitats recognised (Department of the Environment 2014; Lynch et al. 2013), the scientific literature does not contain evidence of any confirmed aggregation sites in WA. A study by Chidlow et al. (2006) failed to confirm anecdotal evidence of possible aggregations observed by divers, commercial fishers and boat charter operators.

The aim of the present study was to utilize extensive underwater video footage from the Point Murat Navy Pier, Exmouth, on Western Australia's North West Cape to determine if this location is an aggregation site for $C$. taurus by identifying individual sharks using spot patterns and recording philopatry at the site; determining any differences in abundance between seasons; recording and comparing sex ratios between seasons and years; recording water temperature and determining correlation with shark occurrence at the site; and to discuss the findings within the context of the Western Australian population.

\section{Methods}

The Point Murat Navy Pier (Navy Pier) is located on the tip of the North West Cape, $16 \mathrm{~km}$ north of Exmouth, Western Australia (21⒋013’S, $114^{\circ} 11.489^{\prime} \mathrm{E}$, Fig. 1). The Navy Pier was constructed in 1964 to service the US Naval Communication Station, built to supply very low frequency radio communication to US submarines (Australian Heritage Database 2002). It is now used primarily by fuel ships supplying the base, with no access to the general public apart from SCUBA diving tours through a local dive company.

The Navy Pier consists of a long vehicle jetty from Point Murat out to the main pier head which is located $175 \mathrm{~m}$ offshore in water depths of up to $15 \mathrm{~m}$. The pier head is constructed of cylindrical steel pylons and cross beams, and covers an area of approximately $50 \mathrm{~m} \times$ $25 \mathrm{~m}$. Two smaller dolphin structures are connected by a walkway to the main pier, and there are two additional isolated mooring dolphins $130 \mathrm{~m}$ to the north and south. The Navy Pier is located at the mouth of Exmouth Gulf and is adjacent to Bundegi Reef in the Ningaloo Marine Park. The marine life in the waters $400 \mathrm{~m}$ around the Navy Pier structure has had some level of protection since 1964 as a prohibited area under the Commonwealth 


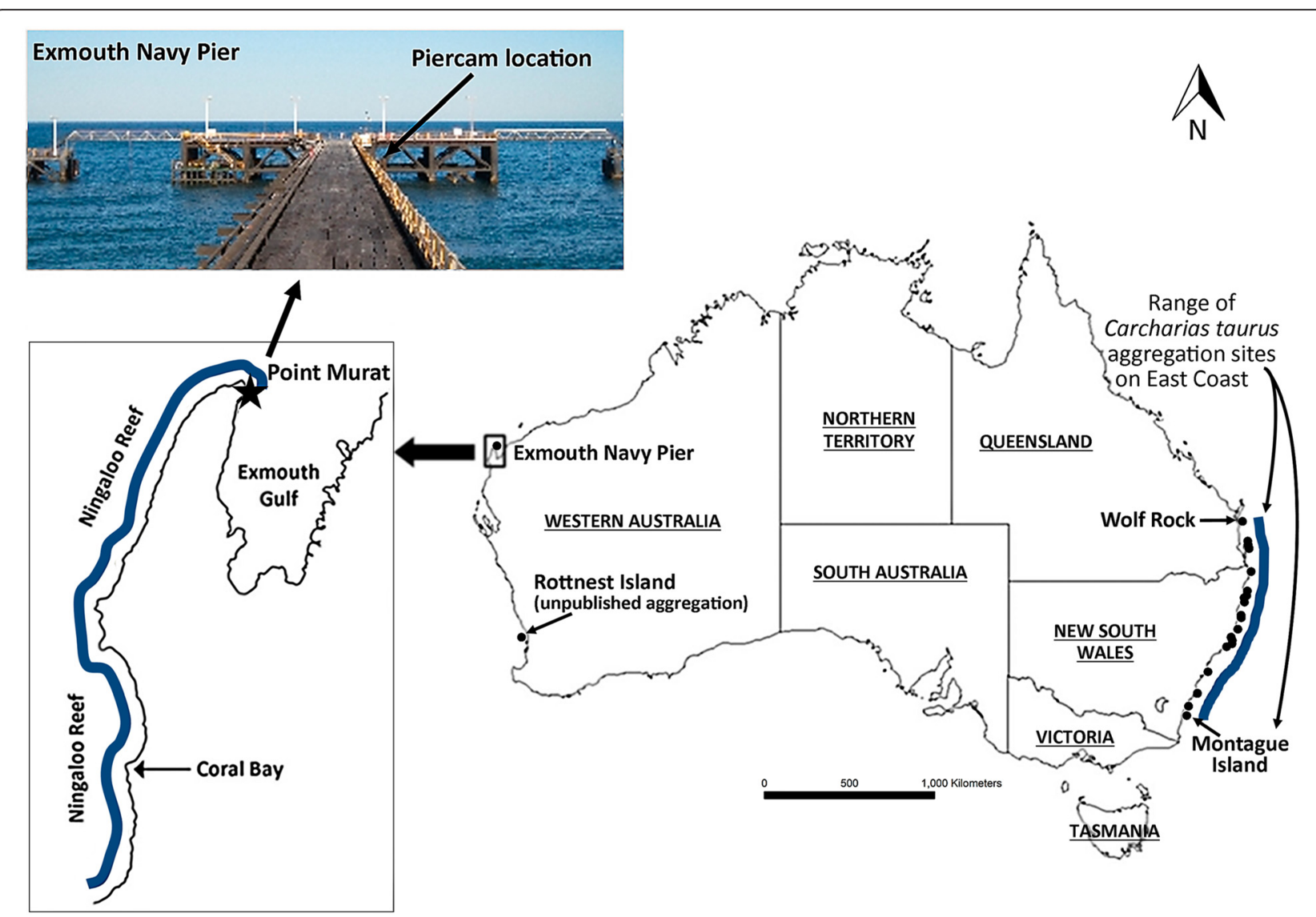

Fig. 1 The Point Murat Navy Pier, Western Australia, showing the location of Piercam and a comparison with the latitude of documented aggregation sites on the East Coast of Australia

Defence (Special Undertakings) Act 1952. In 2005 an additional area surrounding the Commonwealth waters was included in the Ningaloo Marine Park as the Point Murat Sanctuary Zone (CALM 2005). Surveys of marine life associated with the Navy Pier have shown high biodiversity, including over 160 species of finfish representing 50 families (Whisson and Hoschke 2013).

A Weldex WDB-7700CW colour submersible bullet camera with a $3.6 \mathrm{~mm}$ lens and low light infrared illuminators was used to record video footage during daylight hours. The camera was permanently fixed to a steel pier support pylon at a water depth of $10 \mathrm{~m}$ relative to the lowest astronomical tide (LAT), at a height of $1.3 \mathrm{~m}$ above the sea floor. The analogue video stream was encoded, digitized, amplified and sent $15 \mathrm{~km}$ via wireless transmitter to a receiver in the Exmouth town centre, where it was uploaded live onto the World Wide Web (the "Piercam" project). Video footage between September 2007 and February 2012 was reviewed and any occurrence of $C$. taurus documented. There were intervals when no data was recorded due to camera failure or power disruption, and also periods when visibility was too poor to identify sharks (e.g. low light, high turbidity or growth obscuring the camera lens).
Where visibility was adequate, snapshots of the sharks were extracted and used to build a database of individuals, which were visually identified by their distinctive markings including spot patterns and fin shape. Carcharias taurus features distinct natural markings on its sides that have been used to uniquely identify them in monitoring studies (Bansemer and Bennett 2009; Barker and Williamson 2010). These spots are suitable for individual shark recognition as the patterns do not change over time (Bansemer and Bennett 2008). Individual shark identification was greatly enhanced by the matching of spot patterns on both the left and right sides of all sharks identified, which was possible due to the extensive video footage of each shark taken over the course of the study, and distinctive scarring/fin shape of some sharks. Length estimations were based on total shark body length relative to sub-surface structures of known size within the camera's field of view (e.g. pylons or cross beams), and by comparison to one of the males (M3), which was measured accurately in July 2014 by noting points of reference on the sediment for nose and tail while the shark was stationary just above the sea floor. These points were then measured with a tape and the 
process repeated on three occasions to confirm accuracy. Sharks were considered juveniles up to $1.8 \mathrm{~m}$ (Dicken et al. 2006) and mature at $2.2 \mathrm{~m} \mathrm{TL}$ (females) and $1.9 \mathrm{~m}$ TL (males) (Last and Stevens 2009).

Water temperature was measured at 30 min intervals from 27 April 2008 to 29 February 2012 using a Stowaway Tidbit logger (model TBI 32-05 +37 , accuracy $\pm 0.2{ }^{\circ} \mathrm{C}$ ) installed at a water depth of approximately $5 \mathrm{~m}$ (relative to LAT) directly above the camera. No temperature data was recorded for the periods: 29/11/2009 - 8/12/2009 and 7/10/2011 - 18/11/2011.

A two-way ANOVA incorporating year and season was applied to log-linear transformed abundance data, which were relatively low at this site in all years (i.e. maximum of ten individual sharks in any year of the study). Post hoc pair-wise comparisons of abundance data were performed using Scheffe's F Test due to unequal sample sizes (Zar 1974). Sex ratio data were converted to proportion of males after Hardy (2002) and logit-transformed prior to analysis over the period in question. A G-Test (likelihood ratio) was then performed following Williams' correction (Sokal and Rohlf 1981) as all sample sizes were less than 40 (Wiebe and Bortolotti 1992). A Point-Biserial Correlation (Tate 1954) was performed to determine association between water temperature and presence-absence of sharks at the site based on daily mean temperatures.

This study involved the remote observation of sharks and hence no ethics clearance was applicable.

\section{Results}

A total of 16 individual sharks were identified during the 5-year study using spot patterns matched for both the left and right side of each shark combined with any distinctive scarring or fin shapes. Twelve sharks were identified as females and estimated to be between 1.8 and $3 \mathrm{~m}$ TL (subadult to adult) and four sharks as subadult or adult males (>1.8 m TL). The largest male (M1) was estimated at $3 \mathrm{~m}$ TL with full length claspers, while males M2, M3 and M4 were estimated to be between 2 and $2.5 \mathrm{~m}$ TL with claspers extending less than half the distance between the rear edge of the pelvic fin and the start of the anal fin. M3 was subsequently measured accurately at $2.6 \mathrm{~m}(+/-0.05 \mathrm{~m})$ in July 2014 when he was at least 7 years old (having been first recorded at the site in September 2009); however, his claspers appeared under-developed or stunted (Fig. 2). No pups or juveniles (i.e. less than $1.8 \mathrm{~m} \mathrm{TL}$ ) were seen throughout the 5-year study.

Carcharias taurus displayed strong philopatry, with ten individuals returning to the site over multiple years (Table 1). Females displayed varying patterns of site philopatry: two females (F1, F5) returned 2 years after they were initially observed and five individuals (F2, F3, F4, F8, F9) returned over

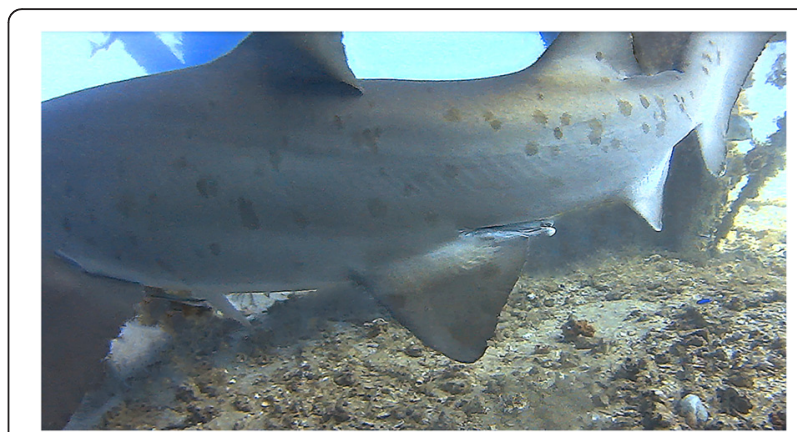

Fig. 2 Underdeveloped claspers on 2.6 m, 7+ year old male Carcharias taurus (M3) at Point Murat Navy Pier, Exmouth, Western Australia

three consecutive years. Males also returned over consecutive years, apart from M2 which was only seen for a few days in 2007. Sharks were usually observed swimming alone, often repeatedly appearing in front of the camera in a circling pattern. Chasing behaviour was occasionally observed and a female (F1) was seen displaying atypical behaviour in September 2007 with her back postured in an inverse arch when swimming and circling at close proximity to a male. Some female sharks (F5 in September 2007; F10 in August 2009; and F9 at the end of August 2011) were observed with fresh biting scars around their pectoral fin regions, the

Table 1 Residence periods ${ }^{a)}$ of Carcharias taurus at the Point Murat Navy Pier

\begin{tabular}{|c|c|c|c|c|c|c|}
\hline $\begin{array}{l}\text { Shark } \\
\text { ID }\end{array}$ & Maturity $^{\mathrm{b})}$ & 2007 & 2008 & 2009 & 2010 & 2011 \\
\hline F1 & M & $12(6)$ & & $12(3) \mathrm{s}$ & & \\
\hline F2 & M & $5(4)$ & $51(6)$ & $33(5)$ & & \\
\hline F3 & $M$ & $34(5)$ & $91(2)$ & $38(2)$ & & \\
\hline $\mathrm{F} 4$ & $?$ & $33(10) \mathrm{s}$ & $18(5)$ & 7 (3) s & & \\
\hline F5 & $M$ & $3(3) \mathrm{ms}$ & & $1(1)$ & & \\
\hline F6 & 1 & $31(10) \mathrm{s}$ & & & & \\
\hline F7 & 1 & $21(3)$ & & & & \\
\hline F8 & $M$ & & $70(3)$ & 76 (16) & 94 (13) s & \\
\hline F9 & M & & & $68(6)$ & $125(7)$ & 122 (14) ms \\
\hline F10 & $M$ & & & $41(6) \mathrm{ms}$ & & \\
\hline F11 & $M$ & & & & $4(4)$ & \\
\hline F12 & $M$ & & & & & $15(3)$ \\
\hline M1 & M & $23(6)$ & $25(4)$ & $36(4) \mathrm{ms}$ & $3(2)$ & \\
\hline $\mathrm{M} 2$ & $?$ & $4(3)$ & & & & \\
\hline M3 & $?$ & & & $11(3)$ & 87 (10) & 145 (18) s \\
\hline M4 & $?$ & & & & $12(10) \mathrm{s}$ & $2(2)$ \\
\hline
\end{tabular}

a) Residence periods were calculated as the number of days between when an individual shark was first sighted and last sighted each calendar year b) Maturity determined from estimated TL

Figures in parentheses represent the number of days with confirmed sightings during the residence period

$F$ females, $M$ males, $m$ mature, $i$ immature, ? uncertain, $s$ fresh scarring, $m s$ fresh scarring attributed to mating 
mature male (M1) also appeared to have fresh bite marks in July 2009. Two of the females with mating scars (F5 and F10) did not return to the Navy Pier the following year, although F5 returned 2 years later. No sharks were observed with attached fishing gear or other injuries caused by fishing, although subsequent observations by the authors indicate fishing-related injuries do occur at this site.

Occurrence of $C$. taurus at the Navy Pier was highly correlated with ocean temperature $\left(\mathrm{r}_{\mathrm{pb}}=0.28 ; p<0.01, n=1290\right)$, with sharks preferring the cooler months, and were never observed when mean daily ocean temperatures exceeded $25.5{ }^{\circ} \mathrm{C}$. Abundance of $C$. taurus was also strongly correlated with season $(p<$ 0.01 ), with shark numbers significantly higher in winter/spring compared to autumn/summer (Fig. 3). No significant differences existed between any years of the study for shark abundance $(p>$ 0.05 ), and no significant interactions existed for SEASON*YEAR from the two-factor ANOVA $(p>0.05)$. The earliest date any grey nurse shark was observed during a calendar year was May 19 (2011), and the latest was November 22 (2008). No grey nurse sharks were seen in any year in the months of December, January, February, March, or April. Mean monthly sea temperatures recorded during the study ranged from $21.0^{\circ} \mathrm{C}$ in July 2010 to $30.3{ }^{\circ} \mathrm{C}$ in January 2011.

Residence period was approximated using the total number of days between the first date and last date an individual shark was observed at the Navy Pier each year. Confirmed observations within the residence period are given in Table 1 . The average residence period over the entire study was 39.8 ( $\pm 6.8 \mathrm{SE}$ ) days per year, with a maximum period of 125 days for a female (F9) in 2010 and 145 days for a male (M3) in 2011. The maximum number of individual sharks identified in any one day was five females on 10 July 2009. Over the entire survey from December 2007 to February 2012, the overall sex ratio was 1:3 (males:females), demonstrating significant female bias at the site $(G=4.19, p<0.05)$. The only year in which a significant female bias was not observed was in 2011 when the sex ratio was 1:1.

While the annual arrival of females always preceded males, a single predominant male was present each year. The decline in annual residence period of $\mathrm{M} 1$, a large mature male that returned to the site over four consecutive years (2007-2010), coincided with the appearance of two smaller males, M3 and M4, in 2009 and 2010 (Fig. 4). While M4 was only observed on 2 days in 2011, the residence periods of M3 increased from 11 to 87 to 145 days in consecutive years (2009-2011) (this male has since been photographed at the site in 2012, 2013 and 2014). M3 and M1 were never observed together.

\section{Discussion}

Occasional $C$. taurus sightings have been reported by dive operators and fishermen in the Exmouth region and other coastal locations in WA for a number of years
(Chidlow et al. 2006); however, there is little published information on this population, and previous studies attempting to confirm aggregation sites anywhere in WA have been unsuccessful (Chidlow et al. 2006). This may, in part, be explained by the seasonal nature of both diving activity and shark occurrence at possible aggregation sites, which are both linked to water temperature. For example, the survey of ten sites in Exmouth in 2005 reported in Chidlow et al. (Chidlow et al. 2006) occurred between May 4 and 8; whereas the earliest grey nurse sharks were observed in any calendar year in the current study in Exmouth (2007-2012) was May 19. In the present study 16 individual grey nurse sharks were documented between 2007 and 2012, with ten individuals returning over multiple years and between four and ten different sharks observed every year, confirming the Point Murat Navy Pier in Exmouth as an aggregation site for C. taurus. Crosschecking of diver observations made concurrently with the Piercam video data indicated that the total number of individual sharks identified was likely to be close to a census of $C$. taurus at the site, and also helped confirm the first and last dates that sharks were seen in any calendar year. Positive identifications could only be made when spot markings or distinctive scars/fin shapes were visible on the sharks, which depended on the distance of the shark from the camera and also the orientation of the shark with respect to the camera lens. The Pier is impacted by strong tidal currents (maximum tidal range $2.6 \mathrm{~m}$ ) and tropical storms which increase the turbidity of the water and limit shark observations and identifications. Observations were also limited by occasional power outages and encrusting growth on the camera lens.

The location of the Exmouth Navy Pier is approximately $450 \mathrm{~km}$ further north than Wolf Rock in Queensland (Fig. 1), which is the northernmost aggregation site currently documented in eastern Australia (25 54.630'S $\left.153^{\circ} 11.800^{\prime} \mathrm{E}\right)$ (Bansemer and Bennett 2009). While there was no direct evidence of pregnancy or pupping at the Navy Pier during the study, fresh mating scars were observed on some sharks in July, August, and September; and although not as intense as mating scarring reported from aggregation sites in Queensland (C. Bansemer pers. comm.), the comparatively moderate scarring may be indicative of mating by a single male as opposed to the multiple males often recorded at other aggregation sites. It is also noteworthy that the evidence of mating activity in the present study is earlier than has been documented in other populations e.g. along the east coast of Africa where mating occurs in October and November (Dicken et al. 2007), and Wolf Rock in Queensland where fresh mating scars were observed in November and December (Bansemer and Bennett 2009). It is possible that the scarring observed may reflect pre-mating behavior with the sharks leaving the site to mate/gestate elsewhere. It 


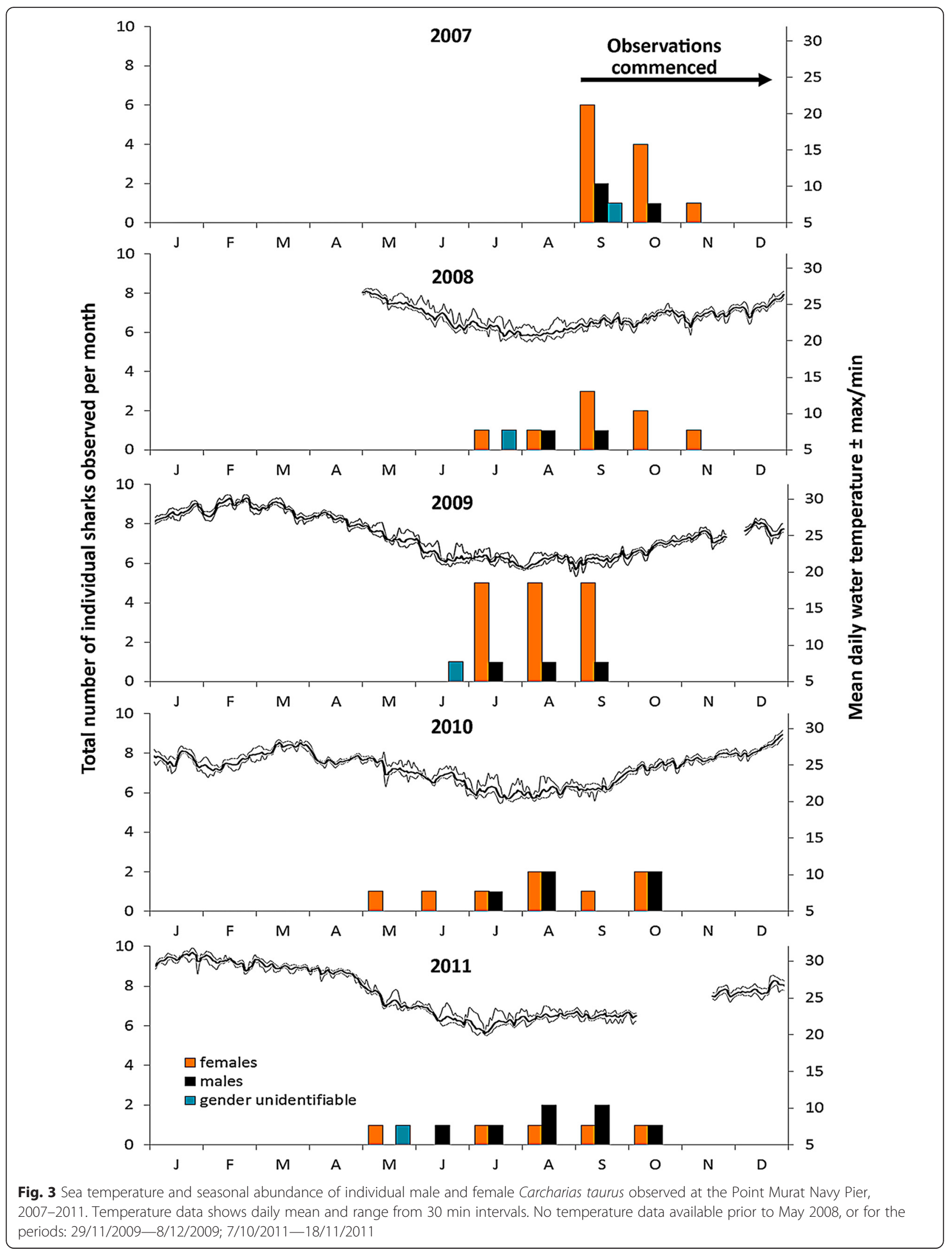




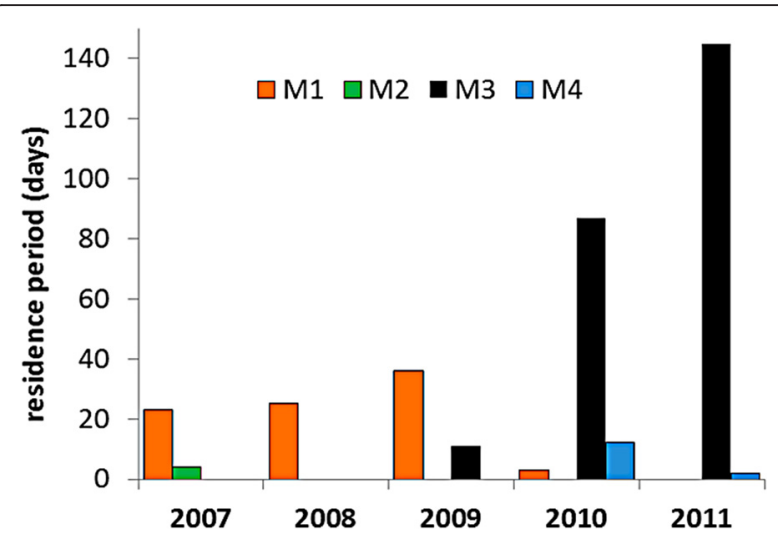

Fig. 4 Decline (M1) and emergence (M3) of predominant male Carcharias taurus at the Point Murat Navy Pier, 2007-2011. Residence period was calculated as the number of days between when an individual shark was first sighted and last sighted each calendar year. $\mathrm{M}=$ male $\mathrm{C}$. taurus

is also likely that some of the sharks at the Navy Pier are subadults (Table 1), which may explain the lack of scarring on some of the females. This is in contrast to the East Coast population where the most northern documented site is almost exclusively occupied by mature sharks (Bansemer and Bennett 2009) and subadults remain at sites further south, and often at shallower depths than the mating aggregation sites (C. Bansemer pers. comm.). The water depth at the Navy Pier varies between 10 and $15 \mathrm{~m}$ depending on location and tides, whereas water depths at Wolf Rock are up to $35 \mathrm{~m}$ (Bansemer and Bennett 2009). At Wolf Rock pregnant females have been observed gestating at the site up until the following August or September, and are presumed to move at least $500 \mathrm{~km}$ south to give birth (Bansemer and Bennett 2009). At the Navy Pier all sharks disappear in November with rising sea temperatures and none are visibly pregnant; however, two females returned 2 years after they were first identified and two females with scarring did not return to the site the following year possibly indicating a biennial reproductive cycle.

It is unclear from this study whether the male M3 was fully mature, as despite his age (at least 7 years confirmed) and size, he appeared to have poorly developed claspers (Fig. 2). M3 was first identified in September 2009 and estimated to be between 1.7 and $2 \mathrm{~m}$ TL (i.e. not juvenile), and was accurately measured at the Pier in July 2014 at $2.6 \pm 0.05 \mathrm{~m}$. Accepted length/maturity classifications (Goldman et al. 2006; Bass et al. 1975; Lucifora et al. 2002) suggest he should be a mature adult. Although accurate length measurements are not available for the other two males M2 and M4 (also noted with short claspers), they were both estimated to be over $2 \mathrm{~m}$ TL. Possible explanations for the atypical presentation of claspers observed in this study include: maturation of males at greater ages and sizes than has been reported for other populations; abnormal clasper development; or anatomical/physiological differences between this genetically distinct subpopulation.

Residence data of $C$. taurus at this site indicated the presence of a single, predominant male at each year (Fig. 4). It is noteworthy that the emergence of M3 appeared to coincide with the departure of M1 after three consecutive years as the lone male at the site. Further, the only other two males observed appeared only over 4 days (M2 in 2007), 12 days (M4 in 2010) and 2 days (M4 in 2011) in any one year, corresponding with much higher residence periods of the predominant male. Although there is little information available on the dynamics of small wild aggregations of $C$. taurus, some reports support the notion of dominance among males, which could explain the female-biased sex ratios observed in the present study. Pre-copulatory aggression has been observed between males in male-biased $C$. taurus aggregations (Lucifora et al. 2002) and dominance by a single male was consistently observed in a long-term study of a nurse shark (Ginglymostoma cirratum) aggregation by Pratt and Carrier (2005) in Florida. Dominance hierarchies have been observed among male C. taurus in captivity (Henningsen et al. 2009) with Gordon (1993) noting that intraspecific male aggression included both immature and mature sharks in a small captive population $(n=8)$ where a dominant male engaged in mate-guarding behaviour by attempting to physically exclude rivals from female sharks. While there is an obvious benefit in males monopolising a receptive female, it is somewhat inconsistent with the premise of polyandry, which sees competition between males continue in the female reproductive tract where sperm compete to achieve fertilisation (Birkhead and Pizzari 2002). Polyandry, by necessity, requires the presence of multiple males; however, it is unclear how polyandrous species like C. taurus behave in small wild aggregations where a single male could be monopolising the immediate site through competitive exclusion. A wide range of sex ratios have been reported among subpopulations for C. taurus (Otway et al. 2003; Bansemer and Bennett 2009; Dicken 2006) including many reports of femalebiased aggregations (Bass et al. 1975; Clark and von Schmidt 1965; Gilmore et al. 1983). While this is mainly a consequence of the sex/maturity of the sharks and associated migration patterns (Bansemer and Bennett 2011; Parker and Bucher 2000), the variations between subpopulations remains unclear. Given that sex ratios are likely to vary under different spatial and temporal conditions, further research is recommended into the nature and prevalence of dominance/competition between males in smaller, female-biased aggregations, like the one observed in the present study, which may be 
more likely to incorporate a single prominent male, and possibly more akin to $C$. taurus dynamics in captive scenarios.

During the study, sharks only appeared when the sea temperature fell below an entry threshold of about $24{ }^{\circ} \mathrm{C}$, which is consistent with tagging data from 15 grey nurse sharks on the east coast of Australia, where both males and females were observed to spend $95 \%$ of their time in sea temperatures between 17 and $24{ }^{\circ} \mathrm{C}$ (Otway and Ellis 2011). An increase in sea temperatures could affect the realised niche of $C$. taurus at the Navy Pier, which in turn may impact their mating/migration patterns. In 2011 a "marine heat wave" was recorded off the WA coast (Pearce and Feng 2013) with mean daily sea temperatures at the Navy Pier in January, February and March 2011 recorded at 30.3, 29.8 and $29.3{ }^{\circ} \mathrm{C}$ respectively. Mean daily temperatures only exceeded $29{ }^{\circ} \mathrm{C}$ in one other month February $2009\left(29.2{ }^{\circ} \mathrm{C}\right)$ over the entire study period (i.e. 17 consecutive seasons). It is noteworthy that the lowest number of individual sharks was recorded in 2011 and it was also the only year where a female-bias was not observed $($ sex ratio $=1: 1)$. The high correlation between seasonal occurrence of $C$. taurus and lower water temperatures at the Navy Pier, combined with this site being the northernmost documented in Australia, make this small aggregation worthy of ongoing monitoring with respect to changing ocean temperatures and any changes to the range and migration patterns of this species.

Otway et al. (2003) defined 'aggregation sites' for $C$. taurus as: locations where five or more grey nurse sharks were consistently found throughout the year. This definition was developed in the context of the eastern population of C. taurus in Australia where researchers have developed a significant database of the associated population parameters over recent decades. We suggest that this definition requires broadening to include seasonal aggregation sites associated with other $C$. taurus populations around the world, including locations in Western Australia. Given the movement and migration patterns of $C$. taurus at various life cycle stages, such aggregation sites may be of great importance, particularly when located near range limits, like the Point Murat Navy Pier, and likely to play a role as future barometers of potential range shifts for $C$. taurus should ocean temperatures change. Further, to exclude seasonal aggregation sites simply from a definitional perspective could have serious ramifications when constructing and applying relevant policies, thereby limiting protection of this species. In particular, sites where reproductive philopatry occurs are of particular importance for threatened shark species (Speed et al. 2010; Tillett et al. 2012). Therefore, we propose a re-definition of $C$. taurus aggregation sites that will encompass locations like the Point Murat Navy Pier in Western Australia.

\section{Aggregation sites for Carcharias taurus are defined as: \\ "locations where five or more Carcharias taurus \\ gather on a recurrent basis each year"}

Ongoing monitoring of local ocean temperatures and C. taurus population characteristics at the Navy Pier is recommended, as the site may be an effective barometer of range shifts for this species. Despite being listed as Vulnerable under the EPBC Act 1999 in WA, there is extremely limited information on C. taurus in this State, and its totally protected status within Australian waters since 1997 means there is no contemporary population reference data owing to the absence of bycatch data from demersal fisheries, which had previously been used to estimate population parameters (McAuley and Simpfendorfer 1994). The monitoring of the C. taurus aggregation at the Point Murat Navy Pier using underwater video surveillance has proven to be an effective and non-invasive tool, not only for identifying and protecting an important aggregation site, but also as a means of gathering population data for this protected species in Western Australia.

While there are no other confirmed aggregation sites documented in the scientific literature for $C$. taurus in WA at this time, recent observations by the authors indicate at least two likely aggregation sites in $20-30 \mathrm{~m}$ water depth near Rottnest Island, and a further site at $40 \mathrm{~m}$ depth offshore from Ledge Point, WA. These, and other sites, require further study to determine their status as aggregation sites for $C$. taurus, as this information will underpin the approach to managing this vulnerable species.

\section{Conclusions}

While the study revealed a comparatively small gathering of $C$. taurus, the systematic nature of visitations by individual sharks over a number of years qualifies the location as a noteworthy aggregation site, the first ever confirmed in Western Australia, and the northernmost documented for C. taurus in Australia to date.

\section{Competing interests \\ The authors declare that they have no competing interests.}

\section{Authors' contributions}

Both authors contributed equally to all aspects of project design, construction, processing, interpretation and manuscript preparation/submission. Both authors read and approved the final manuscript.

\section{Acknowledgements}

We acknowledge the Department of Defence Naval Communication Station Harold E Holt for permitting access to the Point Murat Navy Pier for camera installation and maintenance. We would like to thank local individuals and organisations who contributed to the project: Paul Weall (Boeing), Brian Reading (Exmouth Light Engineering), Ningaloo Dreaming, Ningaloo Whaleshark-n-Dive and Exmouth Diving Centre. We also acknowledge 
Phoebe Sampson and the School of Science at Curtin University and, in particular, Coastal Zone Management students for support.

\section{Funding}

Curtin University (Perth, Western Australia) contributed to the original Piercam project in 2004 via a flexible teaching initiative supporting the Coastal Zone Management programme.

\section{Received: 19 February 2016 Accepted: 23 February 2016}

\section{Published online: 04 April 2016}

\section{References}

Ahonen $\mathrm{H}$, Harcourt RG, Stow AJ. Nuclear and mitochondrial DNA reveals isolation of imperilled grey nurse shark populations (Carcharias taurus). Mol Ecol. 2009;18:4409-21.

Australian Heritage Database. Naval Communication Station Harold E Holt (Area A), Exmouth, WA, Australia, Australian Heritage database report 103552. 2002. http://www.environment.gov.au/cgi-bin/ahdb/search.pl?mode=place detail\&place id=103552. Accessed 18 Feb 2016.

Bansemer CS, Bennett MB. Multi-year validation of photographic identification of grey nurse sharks, Carcharias taurus, and applications for non-invasive conservation research. Mar Freshwater Res. 2008;59:322-31.

Bansemer CS, Bennett MB. Reproductive periodicity, localised movements and behavioural segregation of pregnant Carcharias taurus at Wolf Rock, Southeast Queensland, Australia. Mar Ecol Prog Ser. 2009;374:215-27.

Bansemer CS, Bennett MB. Sex- and maturity-based differences in movement and migration patterns of grey nurse shark, Carcharias taurus, along the eastern coast of Australia. Mar Freshwater Res. 2011;62:596-606.

Barker SM, Williamson JE. Collaborative photo-identification and monitoring of grey nurse sharks (Carcharias taurus) at key aggregation sites along the eastern coast of Australia. Mar Freshwater Res. 2010;61:971-9.

Bass AJ, D'Aubrey JD, Kistnasamy N. Sharks of the east coast of Southern Africa. IV. The families, Odontaspididae, Scaponorhynichidae, Isuridae, Cetorhinidae, Alopiidae, Orectolobidae and Rhiniodontidae. Oceanographic Res Inst Investig Rep. 1975;39:6-16.

Birkhead TR, Pizzari T. Evolution of Sex: Postcopulatory sexual selection. Nat Rev Genet. 2002:3:262-73.

CALM. Management Plan for the Ningaloo Marine Park and Muiron Islands Marine Management Area, 2005-2015: Management Plan No 52. Perth, Western Australia: Department of Conservation and Land Management; 2005.

Cavanagh RD, Kyne PM, Fowler SL, Musick JA, Bennett MB. The conservation status of Australian Chondrichthyans: Report of the IUCN shark specialist group Australia and Oceania regional red list workshop. Brisbane, Australia: The University of Queensland, School of Biomedical Sciences; 2003.

Chidlow, J., Gaughan, D., and McAuley, R. Identification of Western Australian Grey Nurse Shark aggregation sites. Final Report to the Australian Government, Fisheries Research Report 2006; 155. http://www.fish.wa.gov.au/ Documents/research reports/frr155.pdf. Accessed 18 Feb 2016.

Clark E, von Schmidt K. Sharks of the central gulf coast of Florida. Bull Mar Sci. 1965;15:13-83

Compagno LJV. Sharks of the world. An annotated and illustrated catalogue of shark species known to date. Vol. 2: Bullhead, mackerel and carpet sharks (Heterodontiformes, Lamniformes and Orectolobiformes). Rome: Food and Agriculture Organization of the United Nations; 2001.

Department of the Environment. Recovery Plan for the Grey Nurse Shark (Carcharias taurus) 2014. Available at http://www.environment.gov.au/ resource/recovery-plan-grey-nurse-shark-carcharias-taurus. Accessed 18 Feb 2016.

Dicken ML. Population dynamics of the raggedtooth shark (Carcharias taurus) along the east coast of South Africa. Grahamstown, South Africa: PhD Thesis, Rhodes University; 2006. p. 241.

Dicken ML, Smale MJ, Booth AJ. Spatial and seasonal distribution patterns of the ragged tooth shark (Carcharias taurus) along the coast of South Africa. African J Mar Sc. 2006;28:603-16.

Dicken ML, Booth AJ, Smale MJ, Cliff G. Spatial and seasonal distribution patterns of juvenile and adult ragged tooth sharks (Carcharias taurus) tagged off the east coast of South Africa. Mar Freshwater Res. 2007;58:127-34.

Ebert DA, Fowler SL, Compagno L, Dando M. Sharks of the world. A fully illustrated guide. Plymouth: Wild Nature Press; 2013.

Gilmore RG, Dodrill JW, Linley PA. Reproduction and embryonic development of the sand tiger shark, Odontaspis taurus (Rafinesque). Fish Bull. 1983:81:201-25.
Goldman KJ, Branstetter S, Musick JA. A re-examination of the age and growth of sand tiger sharks, Carcharias taurus, in the western North Atlantic: the importance of ageing protocols and use of multiple back-calculation techniques. Environ Biol Fishes. 2006;77:241-52.

Gordon I. Pre-copulatory behaviour of captive sand tiger sharks, Carcharias taurus. Environ Biol Fishes. 1993;38:159-64.

Hardy ICW (ed). Sex ratios: Concepts and research methods. Cambridge, United Kingdom: Cambridge University Press; 2002. p. 424.

Henningsen AD, Murru FL, Rasmussen LEL, Whitaker BR, Violetta GC. Serum levels of reproductive steroid hormones in captive sand tiger sharks, Carcharias taurus (Rafinesque), and comments on their relation to sexual conflicts. Fish Physiol Biochem. 2009;34:437-46.

HL Jr P, Carrier JC. The nurse shark, mating and nursery habitat in the Dry Tortugas, Florida. Am Fish Soc Symp. 2005;47:1-12.

Last PR, Stevens JD. Sharks and rays of Australia. 2nd ed. Australia: CSIRO Division of Fisheries; 2009.

Lucifora LO, Menni RC, Escalante AH. Reproductive ecology and abundance of the sand tiger shark, Carcharias taurus, from the southwestern Atlantic. ICES J Mar Sc. 2002;59:553-61.

Lynch T, Harcourt G, Edgar G, Barrett N. Conservation of the critically endangered Eastern Australian population of the grey nurse shark (Carcharias taurus) through cross-jurisdictional management of a network of marine-protected areas. Environ Manage. 2013;52(6):1341-54.

McAuley R. Western Australian grey nurse shark pop up archival tag project. Final report to department of environment and heritage. 2004.

McAuley R, Simpfendorfer C. Catch composition of the Western Australian temperate demersal gillnet and demersal longline fisheries, 1994-1999. Fisheries Research Report 2003;146. http://www.fish.wa.gov.au/Documents/ research_reports/frr146.pdf. Accessed 18 Feb 2016.

Momigliano P, Jaiteh VF. First records of the grey nurse shark Carcharias taurus (Lamniformes: Odontaspididae) from oceanic coral reefs in the Timor Sea. Mar Biodivers Rec. 2015. doi:10.1017/S1755267215000354.

Otway NM, Ellis MT. Pop-up archival satellite tagging of Carcharias taurus: movements and depth/temperature-related use of south-eastern Australian waters. Mar Freshwater Res. 2011;62:607-20.

Otway NM, Parker PC. The biology, ecology, distribution and abundance, and identification of marine protected areas for the conservation of threatened grey nurse sharks in south east Australian waters. New South Wales Fisheries Final Report Series 2000;19. http://www.dpi.nsw.gov.au/_data/assets/pdf_ file/0004/545602/FFRS-19 Otway-2000.pdf. Accessed 6 Mar 2016.

Otway NM, Burke AL, Morrison NS, Parker PC. Monitoring and identification of NSW critical habitat sites for conservation of grey nurse sharks. New South Wales Fisheries Final Report Series 2003;47. http://www.dpi.nsw.gov.au/_ data/assets/pdf_file/0006/545631/FFRS-47_Otway-et-al-2003.pdf. Accessed 6 Mar 2016.

Parker P, Bucher DJ. Seasonal variation in abundance and sex ratio of grey nurse (sand tiger) sharks Carcharias taurus in northern New South Wales, Australia: A survey based on observations of recreational scuba divers. Pac Conserv Biol. 2000;5:336-46.

Passerotti MS, Andrews AH, Carlson JK, Wintner SP, Goldman KJ, Natanson LJ. Maximum age and missing time in the vertebrae of sand tiger shark (Carcharias taurus): validated lifespan from bomb radiocarbon dating in the western North Atlantic and southwestern Indian Oceans. Mar Freshwater Res. 2014;65:674-87.

Pearce $A F$, Feng $M$. The rise and fall of the "marine heat wave" off Western Australia during the summer of 2010/2011. J Mar Syst. 2013;111-2:139-56.

Pogonoski JJ, Pollard DA, Paxton JR. Conservation Overview and Action Plan for Australian Threatened and Potentially Threatened Marine and Estuarine Fishes. Canberra, ACT: Environment Australia 2002. http://www.environment. gov.au/system/files/resources/ca415225-5626-461c-a929-84744e80ee36/files/ marine-fish.pdf. Accessed 18 Feb 2016.

Pollard D, Smith A. Carcharias taurus. The IUCN Red List of Threatened Species. 2009. e.T3854A10132481. http://dx.doi.org/10.2305/IUCN.UK.2009-2.RLTS. T3854A10132481.en. Accessed 18 Feb 2016.

Pollard DA, Lincoln Smith MP, Smith AK. The biology and conservation status of the grey nurse shark (Carcharias taurus Rafinesque 1810) in New South Wales, Australia. Aquatic Conserv. 1996;6:1-20.

Pollard D, Gordon I, Williams S, Flaherty A, McAuley R. Carcharias taurus (Western Australia subpopulation). The IUCN Red List of Threatened Species. 2003. e. T44071A10854958. http://dx.doi.org/10.2305/IUCN.UK.2003.RLTS. T44071A10854958.en. Accessed 18 Feb 2016. 
Rafinesque (Schmaltz) CS. Caraterri di alcuni nuovi generi e nuove specie di animali (principalmente di pesca) e piante della Sicilia, con varie osservazioni sopra i medisimi. Palermo; 1810. p. 105, 20pls.

Smale M. Occurrence of Carcharias taurus in nursery areas of the Eastern and Western Cape, South Africa. Mar Freshwater Res. 2002;53:551-6.

Sokal RR, Rohlf FJ. Biometry. 2nd ed. San Francisco: W.H. Freeman; 1981.

Speed CW, Field IC, Meekan MJ, Bradshaw CJA. Complexities of coastal shark movements and their implications for management. Mar Ecol Prog Ser. 2010; 408:275-93.

Stow A, Zenger K, Briscoe D, Gillings M, Peddemors VM, Otway N, et al. Isolation and genetic diversity of endangered grey nurse shark (Carcharias taurus) populations. Biol Lett. 2006;2:308-11.

Tate RF. Correlation between a discrete and a continuous variable. Point-Biserial Correlation. Ann Math Stat. 1954;25:603-7.

Tillett BJ, Meekan MG, Field IC, Thorburn DC, Ovenden JR. Evidence for reproductive philopatry in the bull shark Carcharhinus leucas. J Fish Biol. 2012:80:2140-58.

Whisson G, Hoschke A. In situ video monitoring of finfish diversity at Ningaloo Reef, Western Australia. Galaxea (Tokyo) JCRS Special Issue. 2013:72-8. https://www.jstage.jst.go.jp/article/galaxea/15/Supplement/15_72/_pdf. Accessed 18 Feb 2016.

Wiebe K, Bortolotti G. Faculative sex ratio manipulation in American kestrels. Behav Ecol Sociobiol. 1992;30:379-86.

Zar JH. Biostatistical analysis. Englewood Cliffs: Prentice Hall; 1974.

Submit your next manuscript to BioMed Central and we will help you at every step:

- We accept pre-submission inquiries

- Our selector tool helps you to find the most relevant journal

- We provide round the clock customer support

- Convenient online submission

- Thorough peer review

- Inclusion in PubMed and all major indexing services

- Maximum visibility for your research

Submit your manuscript at www.biomedcentral.com/submit
Biomed Central 